\title{
Gendered Quest in Recent Hungarian Fantasy Films
}

\section{Vera Benczik}

\begin{abstract}
Although the fantastic in print looks back upon a tradition of commenting on issues of race and gender, films that use the mode tend to be more conservative in their approach to subverting the patriarchal script, that is, the tendency of patriarchal society prescribing certain normative behaviors based on gender while punishing deviations from these norms. While this is especially true for blockbuster movies, independent filmmaking has come to appreciate the subversive potential of fantasy. The present study will scrutinize the fantastic as a storytelling mechanism in recent Hungarian cinema, with special emphasis on the uses of the quest formula and its intersections with gender scripts in the films Hurok ['Loop'] (2016), and Liza, a rókatündér ['Liza, the Fox-Fairy'] (2015).
\end{abstract}

Keywords: coming-of-age narratives, redemptive narratives, "Groundhog Day" narrative template, female quest vs. male quest, the quest in fantasy/science fiction narratives, gendered quest, the fantastic in Hungarian filmmaking

Biography: Vera Benczik is Senior Assistant Professor at the Department of American Studies, Eötvös Loránd University, Budapest, where she teaches courses on American and Canadian literature, science fiction and popular culture, with research interests mainly in the field of science fiction. Her current projects focus on the spatial discourse of apocalyptic and post-apocalyptic science fiction narratives and the use of place and space in Margaret Atwood's dystopian fiction.benczik.vera@btk.elte.hu

\section{Gendered Quest in Film}

The quest has been a central trope in narration since the dawn of literature. One of the earliest extant literary cycles, stories featuring the mythologically-enhanced historical figure of Gilgamesh, king of Uruk (Mesopotamia, present-day Iraq), features the travels of the titular hero to the land of the dead, and the land beyond time in search for eternal life. While Gilgamesh ultimately fails to achieve immortality, he returns home having gained the wisdom that while death is inevitable, immortality may be achieved by inscribing ourselves into the common cultural narrative. Narratives since then have repeatedly focused on the travels of the hero closely linked to their personal transformation. Well-known examples range from Homer's Odyssey over Gulliver's Travels by Jonathan Swift and Mark Twain's The Adventures of Huckleberry Finn, to modern and contemporary works like Jack Kerouac's On The Road or George R. R. Martin's Song of Ice and Fire series, all by male authors, and all — with the exception of the last—featuring male heroes, a point that will be addressed later on. 
Benczik, Vera. “Gendered Quest in Recent Hungarian Fantasy Films.” Hungarian Cultural Studies. e-Journal of the American Hungarian Educators Association, Volume 12 (2019) DOI: 10.5195/ahea.2019.365

With the prevalence of the trope and its close ties to psychological processes, it is no wonder that the quest came under the scrutiny of several schools of cultural criticism. After the advent of psychoanalysis at the end of the nineteenth century, anthropology and literary criticism soon drew parallels between the quest formula, the journey of life, and various phases of psychological development. Scholars identified an apparent connection between the rites of passage with all its ritual paraphernalia, and the stages of the heroic quests in literature. Following the work of James George Frazer and Arnold van Gennep on mythology, taboo, and the ritual framework surrounding the transition from childhood into adulthood, it was Joseph Campbell who, also drawing upon the theories of Sigmund Freud and Carl Gustav Jung, in his seminal 1949 work The Hero with a Thousand Faces investigated the structure of the quest. As Campbell (2004: 27) says, "the passage of the mythological hero may be over-ground, incidentally; fundamentally it is inward - into depths where obscure resistances are overcome, and long lost, forgotten powers are revivified, to be made available for the transfiguration of the world."

Campbell identifies this archetypal journey as the monomyth, and founds it on the pattern of departure-initiation-return, which, Kathryn Hume (2004: 27) claims, functions as the "externalizations of [the] pattern" of the initiation rituals. The journey invites metaphorical and symbolical interpretations as the hero's rite of passage from innocence to experience, from isolation to integration or re-integration into a community, or conversely, a departure from security and confidence into a world of danger, doubt and corruption. Despite the later scholarly criticism Campbell's work has garnered, and despite its somewhat outdated and reductive aspects, it still remains the basis for the literary analysis of the quest, and has been used extensively by archetypal theoreticians like Northrop Frye or Kathryn Hume. Apart from the direct derivative scholarship which developed Campbell's work further, other, subversive criticism has led to the reformulation of the quest in terms that decentralized the white male heteronormative paradigm which served as the basis for the Campbellian monomyth, in order to integrate the female protagonist as hero, and the female Bildung as quest. Northrop Frye's analysis differs slightly from that of Campbell, as he works less from a psychoanalytical standpoint, but rather from the discursive context of literary criticism; he calls the monomyth "quest romance" ( Frye 1990: 189), and identifies the tripartite structure journey-exaltation-return, adding a transcendental layer to the conscious-unconscious dichotomy invoked by Campbell. Hume adds more emphasis to the spiral nature of the quest in labeling her structure equilibrium-struggle-higher harmony (Hume 1974: 135). Common to all these analyses, and the numerous derivatives they have engendered so far, is that they describe the quest as an archetypal component of literature, as a metaphor or allegory denotative of the psychological process of the rite of passage, and the cultural practices concerned with contextualizing the transition from one human state of existence into another, for example from childhood into adulthood.

The preceding overview of the archetypal journeys? concerns both realist and non-realist literary texts, but the films examined within this article fall in the realm of the fantastic, and the quest as trope occupies a central position in both fantasy and science fiction (henceforth SF): fantasy narratives tend to rely more faithfully on the archetypal mythological apparatus of the quest, while SF uses the formulaic platform to explore the encounter with the Other, often in subversive ways. The present study scrutinizes the fantastic as a storytelling mechanism in recent Hungarian cinema, with special emphasis on the uses of the quest formula in the films Hurok ['Loop'] (2016), and Liza, a rókatündér ['Liza, the Fox-Fairy'] (2015). My analysis will focus on the differences between the male quest, as used by Loop, and the female quest, as presented in Liza, the Fox-Fairy, my thesis being that while in mainstream American cinema of the fantastic the female quest has 
Benczik, Vera. “Gendered Quest in Recent Hungarian Fantasy Films.” Hungarian Cultural Studies. e-Journal of the American Hungarian Educators Association, Volume 12 (2019) DOI: 10.5195/ahea.2019.365

seen a revision both in structure and content, contemporary Hungarian cinema still relies on the traditional female quest within "the realm of domesticity," as defined by Gilbert and Gubar (1987: 205), as far as non-realistic films are concerned.

An interesting trend to note when one analyzes the history of the fantastic in literature and film in terms of its representation of gender, is that the visual modes tend to lag behind literary texts, especially the short stories published in genre magazines. For example, while the British and American New Wave movement of the 1960s - helmed by British author Michael Moorcockbrought with it a diversification of voices and themes in both science fiction and fantasy, and transformed these genres into sites for potential transgressive literary experimentation, film and television remained conservative. Financial concerns may have been the main reason behind this slowness to change, as the production costs and possible profit usually affected the degree of transgression allowed. Gradual change regarding gender representation in the visual media can be seen starting in the late 1970s, with notable examples like Star Wars (1977) and Alien (1979), which both feature strong female lead characters. Alien's Ripley, played by Sigourney Weaver, is especially important in this regard, since her story arc can be decoded as a female quest for independence and empowerment, a rare early occurrence of such a female coming-of-age narrative in a cinematic branch featuring male quest narratives as a norm. Films like Red Sonja (1985) or television series like Xena: Warrior Princess (1995-2001), or Buffy the Vampire Slayer (1997-2003) were all variations on the quest of the female warrior, and became examples of what Réka M. Cristian and Zoltán Dragon call "negotiated cinema... a special type of feminist film [that] takes into consideration the basic elements of traditional visual narratives ... with conscious representation of women in contemporary culture" (Cristian and Dragon 2008). The line of strong female leads in science fiction and fantasy cinema continues, with characters like Katniss Everdeen (the Hunger Game book and film series) or Rey (the most recent installments of the Star Wars franchise) bringing even more complexity to the staging of the female quest.

Unlike American cinema, where both science fiction and fantasy films constitute a substantial part of mainstream and blockbuster releases, where box office records show that eight out of the ten highest grossing films of 2018 were either science fiction or fantasy movies (boxofficemojo.com), Hungarian filmmaking has been and still is at odds with the fantastic, with realistic comedy, drama, and historical films still amounting to the bulk of Hungarian cinematic output, for two principal reasons. On the one hand, fantasy and science fiction films usually entail a larger budget to cover the costs of special effects, and also require companies with the expertise in these fields. On the other hand, Hungarian filmmaking lacks the tradition within the genres of the fantastic that American cinema relies on. In addition to this, as Ákos Varga claims, experimenting with popular genres in Hungarian cinema may also be hindered by the rather traditionalist film financing mechanism of post-communist Hungary (Varga 2016). Despite this relative absence of the fantastic in Hungarian cinema, there is a growing number of films that utilize the toolkit of either science fiction or fantasy, often using "guerilla tactics" (Varga 2016), that is evading central artistic control linked to state financing by trying to accumulate funds from independent sources. In addition to the already mentioned Loop and Liza, the Fox-Fairy Notable post-2000 examples include Kontroll (2001, dir. Nimród Antal), Aura (2014, dir. Zsolt Bernáth),. The following section of my study presents an analysis of the male vs. the female quest in two of these films, Loop and Liza, the Fox-Fairy. 
Benczik, Vera. “Gendered Quest in Recent Hungarian Fantasy Films.” Hungarian Cultural Studies. e-Journal of the American Hungarian Educators Association, Volume 12 (2019) DOI: 10.5195/ahea.2019.365

\section{The male quest for fatherhood in the Film, Hurok ['Loop']}

Loop, as its title suggests, refers to a time loop narrative, a subcategory of the time travel trope that involves the repetition of the same period of time over and over again. It has asserted its presence in both science fiction and fantasy narratives, although, cinematic appearances of the trope are overwhelmingly fantasy narratives (Sherman 2016: 192). The distinction between the modes is fairly simple: if a rational, scientific explanation for the phenomenon is given, it falls into the category of science fiction, but if the reasons for repeating the period remain unexplained, it becomes fantasy. Sherman traces the motif back to Eric Rücker Eddison's 1922 epic fantasy novel The Worm Ouroboros, which ends with time turned back to the beginning of the war central to the narrative, only for the opposing parties to experience it over and over again. Prose examples of the motif range from Malcolm Jameson's 1941 short story "Doubled and Redoubled" over Kurt Vonnegut's Timequake (1997) to J. K. Rowling's Harry Potter and the Prisoner of Azkaban (1999), featuring an elaborate time loop sequence as its central plot device. The blueprint for time loop films in contemporary cinema is probably Groundhog Day (1993), which has become a stepping stone for all such narratives, including Loop. The latest incarnation of the trope, Edge of Tomorrow (2014), directed by Doug Liman and starring Tom Cruise, is one of the rare science fiction examples where the repetition of the day is justified with the time altering abilities of the alien hive mind attacking humanity and Earth.

No matter what genre or mode the time loop narrative is set in, or what moves its plot forward, it very often focuses on the personal development of the protagonist(s), which holds the key to exiting the trap of ever-repeating events. As Ryan Gilbey (2013) notes, time loop films most often fall in line with "classical redemptive narrative[s]." Phil Connors in Groundhog Day can only break the loop after a profound transformation from egocentric loner to an altruistic anchor of the small town community, and while Edge of Tomorrow can be decoded as an allegory of the glorious victory of allied forces in World War II, it is not the panhuman solidarity that ends the repetition, but the underlying development arc of Major William Cage (Cruise), running its course from arrogant and cowardly public relations officer to his transformation into selfless military hero. In terms of its formal categorization, the time loop narrative could arguably be classified as a "portalquest fantasy ... [where] a character leaves her familiar surroundings and passes through a portal into an unknown place" (Mendlesohn 2008: 27). As Mendlesohn goes on to observe, "[a]lthough portal fantasies do not have to be quest fantasies the overwhelming majority are, and the rhetorical position taken by the author/narrator is consistent" (Mendlesohn 2008: 27). Lewis Carroll's Alicebooks, and C. S. Lewis's Narnia Chronicles series spring to mind as the archetypal portal-quest fantasies, and while the rabbit hole and the wardrobe, respectively, are easily recognizable portals, time loop narratives are slightly more tricky in this respect. Here the familiar and estranged territories overlap physically, what constitutes the strangeness of the latter is the hero's knowledge of having gone through the events before, and the portal here is the point in time when the rollback happens. Compare also, for example, Enikő Bollobás, discussing the relationship between reality and fantasy realms in Mark Twain's The Mysterious Stranger, who observes that "the real and the unreal are positioned as polar opposites, making the transfer from one to the other through metalepsis. But this seeming metalepsis will turn out to be intertexuality: the shift between two textual worlds" (Bollobás 2018: 15). This conceptualization is well applicable to the interplay between normal time and the fantastic realm of temporal replay, and offers an adequate explanation for the digression from the traditional portal-quest narrative script. 
Benczik, Vera. “Gendered Quest in Recent Hungarian Fantasy Films.” Hungarian Cultural Studies. e-Journal of the American Hungarian Educators Association, Volume 12 (2019) DOI: 10.5195/ahea.2019.365

Loop, directed by Isti Madarász, and released in 2016 to wide critical acclaim uses the template of the time loop to drive its narrative forward. Its protagonist, Ádám is a small-time drug smuggler who transports pharmaceutical substances over the Hungarian border for his boss, Dezső. Wanting out, he tries to make a last run, intending to keep the profits, and it is at this point that the audience enters the story. He arrives home to find his girlfriend, Anna with a positive pregnancy test, jeopardizing his dreams of wealth and freedom when Anna does not want to consider aborting the baby. After they fall out, Anna goes for a check-up with her doctor, Ádám's father, while Ádám decides to leave her and his unborn child in exchange for the promise of money, and here the loop starts. The film combines a crime action formula with the fantastic element of the time loop, but goes beyond using a simple repetition of events. The different cycles of re-living the events overlap, with characters from separate reruns crossing each other's paths, resulting in the "co-occurrence of two or more disparate, dislocated narrative elements on a homogeneous, blurred narrative plane," to use Pál Hegyi's description of narrating the uncanny (Hegyi 2019). Ádám does not only meet Anna from a different version of events - her death from a car accident being one of the recurring occurrences - , but also encounters himself on more than one occasion, nicely hinting at one of the fundamental time travel paradoxes. The overlay of reruns creates a confusing and chaotic web of causality and teleology that only gets untangled at the very end of the loop. The need for Ádám to come to terms with fatherhood represents the underlying personal quest of the film, and this maps out the cornerstones of the loop: Anna's fatal accident, the conversation with his father, and the conflict with Dezső, the prime antagonist in the drama. The audience is tied to Ádám's character, encountering the same events from different perspectives again and again as the loop repeats while Ádám progresses on his character arc.

Ádám's transformation commences after his shying away from parental responsibility, and learning how to be a father marks the endpoint of his quest. The first loop starts with Ádám urging his girlfriend to have an abortion, then he proceeds to watch her get hit by a car, and he ends the loop by running away. Yet the fear of losing Anna becomes the turning point for Adam, functioning as the catalyst of his personal development, and for the rest of the film, Ádám is motivated by setting things right. When he re-experiences the accident in the second loop, he stays by her side, and consoles her as she is dying, then during the third rerun tries to avert her death without success. In the process Anna and the child transform from burden to objective, and Ádám sets out to protect her and her fetus from Dezső, finally embracing commitment and verbalizing formal familial ties to woman and unborn child, by yelling Hagyd békén a családomat! ['Leave my family alone!'] to Dezső, as the latter is attacking? attacks Anna and Ádám. This in turn propels Adam towards the resolution of the loop. During the fourth rerun Ádám is horrified at the prospect of losing his unborn child when Anna experiences heavy bleeding, at which point he calls her his wife, thus verbally finalizing the acceptance of the formation of the family. The narrative abounds with psychoanalytic metaphors, and the final change in the loop happens after his third incarnation (Ádám3) fights his second incarnation (Ádám2) in the bathroom, killing him(self) in the process. Ádám3 asserts that the murder is necessary to save Anna, accusing Ádám2 to be the person who hagyja Annát meghalni ['would let Anna die'] (Loop 2016). Killing oneself is one of the recurring paradoxes in time-travel stories, and the film obscures any rational explanation of this possibility, instead building on the metaphorical force of the act.

As the foregoing development through the five loops of the narrative concentrates on Ádám's transformation from man-child to father, the film takes a traditional approach to gender representation. Anna is cast in the object position, embodying woman as sexual object, as maternal principle and as damsel in distress, who is in need of the hero's protection. She is catalyzer and 
Benczik, Vera. “Gendered Quest in Recent Hungarian Fantasy Films.” Hungarian Cultural Studies. e-Journal of the American Hungarian Educators Association, Volume 12 (2019) DOI: 10.5195/ahea.2019.365

prize of Ádám's quest while his struggles with the two male characters, his father and Dezső, mark the obstacles that he has to overcome in order to win the prize. Both Dezső and Ádám's father occupy authority positions, Dezső as Ádám's boss and supplier, superior in age, intellect, and strength, while Ádám's father is doubly a father-figure by familial relations, and the intertextual connotations of Ádám's name-Adam as the first man in the Biblical sense, the creation/child of God-, while donning the authority of the medical professional who helps to bring children into this world. If we reduce the narrative to its fairy-tale level Dezsö is clearly the dragon that has to be slain in order for the hero to succeed. Ádám's benevolent and helpful father occupies a more complicated position, but fits perfectly into the Campbellian quest system, which features the double - fear-inducing and benevolent - figure of the father as part of the monomyth. The hospital scene of the final loop, in which Ádám's father confirms the well-being of mother and fetus after the accident marks the stage which Campbell calls the "atonement with the father" in which the hero resolves his problematic relationship with his progenitor and : "beholds the face of the father, understands — and the two are atoned" (Campbell 2004: 135).

The [scene in question ]goes beyond simple atonement as Ádám indeed becomes the father, and ensures that the circle of life will continue with his own son. The gender of the unborn baby had been confirmed by Ádám's father, and upholding the succession of males within the family neatly upholds the male subject and female object positions, as well. The quest seems to be successful, and all points towards a happy ending outside the time loop. The final shot reveals itself as a reiteration of the first scene on the subway, pointing at the possibility of prolonged entrapment within time.

\section{The female quest for domesticity: Liza, the Fox-Fairy}

Liza, the Fox-Fairy (henceforth Liza), the first feature directed by Károly Ujj Mészáros, was, both commercially and critically, one of the most successful Hungarian films in 2015. Using Mendlesohn's taxonomy, Liza is an "immersive fantasy... set in a world built so that it functions on all levels as a complete world" (Mendlesohn 2008: 89), located in a fantastic city based on Budapest, and named Csudapest ['Wonderpest'], a play on the words 'csuda' [wonder] and Buda. The film may also be categorized as an urban fantasy, where, according to Alexander C. Irvine, authors may use the cityscape in two basic ways, "either an existing city [is] made fantastical or a fantastical city [is] made real" (Irvine 2012: 204). I would locate Liza's Csudapest somewhere in the middle of this spectrum, as both Budapest and Hungary remain recognizable, yet the world itself is undeniably distanced from experiential reality. The visual characteristics of the film endow it with the "quirky sensibility" attributed to Wes Anderson's movies by James MacDowell. When writing about "quirky" as an aesthetic category in contemporary cinema, MacDowell (2012: 8-9) defines its characteristics as a combination of "various types of comedy... deadpan... comedy of embarrassment ...slapstick" (, coupled with a "feeling of slight absurdity," a tendency to use metacinematic devices, to rely on the rigidity of arranged symmetry, a simple and bright color scheme and exhibit and underline a certain "kind of naïveté" which "in turn reflects the sensibility's frequent preoccupation with innocence more generally.". It is this fantastic cityscape that the titular character, Liza, played by Móni Balsai, has to navigate in her quest for true love. In the present study I will argue and despite the focus on a strong female lead's coming of age narrative, the heroine's quest is a female quest for domesticity and ideal womanhood, so that the film ultimately conforms to the heteronormative patriarchal ideal of gender roles. 
Benczik, Vera. “Gendered Quest in Recent Hungarian Fantasy Films.” Hungarian Cultural Studies. e-Journal of the American Hungarian Educators Association, Volume 12 (2019) DOI: 10.5195/ahea.2019.365

The title Liza, the Fox-Fairy marks the close relationship between the movie and the genre of the fairy tale, a layer that was only implicitly present in Loop through its use of the archetypal quest narrative. Feminist revisions of fairy tales have become popular among writers in the second half of the twentieth century, with authors like Tanith Lee, Angela Carter, or Neil Gaiman, all using the traditional fairy tale scripts to comment on and subvert the prescriptive social and cultural practices of patriarchal society. This meant the rehabilitation of evil - yet strong and independentfemale characters like the stepmother/queen/witch in "Snow White" (in the works of Tanith Lee, Neil Gaiman), the empowerment and de-victimization of the female protagonists in stories like "Little Red Riding Hood" (in Angela Carter), and Bluebeard's Castle (in Angela Carter and Tanith Lee). The fairy tale script Liza seemingly employs most overtly centers around the figure of fox spirit in Japanese culture. Similarly to its male incarnations in Western folklore, in Japanese mythology the female fox occupies the trickster position, not only "a magical temptress of men ... a playful spook ... a possessing spirit", but also "the foremost of the bakemono, shapeshifters able to influence others' perception of themselves in the world" (Bathgate 2004: x, xiii). Yet as it turns out during the course of the film, Liza's self-identification with the fox-fairy is a trick played on her by the ghost of Tomy Tani. Introduced as the spectral presence of a deceased Japanese pop musician whom only Liza can see and communicate with, Tomy Tani is in reality Death in disguise, and thus the real shapeshifting trickster figure of the narrative, who manipulates Liza in order to entice her to commit suicide and enter his realm for good. The fairy tale script pertinent to Liza herself is rather that of Snow White, and Sandra M. Gilbert and Susan Gubar's analysis of the fairy tale can be mapped onto Liza's narrative, as well. Gilbert and Gubar conclude that Snow White has to embark on an "education in submissive femininity, for in serving them [the dwarves] she learns essential lessons of service, of selflessness, of domesticity" (Gilbert and Gubar 1987: 205). Thus, ultimately Liza's quest is not that of the empowered and independent trickster, but that of the conventional girl learning to successfully inhabit patriarchal gender scripts, which will reward her with true love.

Liza sets out on her rite of passage when Márta Tanaka, the widow of a former Japanese ambassador dies, and leaves her the apartment they lived in. Bereft of her mother figure, Lizawhose infantile portrayal belies her age-finally has to grow up, and the transition from girlhood into womanhood means acquiring the skills of the true woman. Her personality rhymes very well with how Gilbert and Gubar describe Snow White as "childlike, docile, submissive, the heroine of a life that has no story" (Gilbert and Gubar 1987: 203; emphasis in the original).The film outlines Csudapest as a patriarchal world with strictly segregated gender roles, where men have agency and can either be benevolent father- or husband figures, or malevolent carnivores, while women can only have patiency,. Male characters occupy all positions of authority: the narrator's god-like figure, the policemen, the contract killer, doctors, lovers, CEOs, the hero to save Liza from death, even Death himself, are all male. Women are only cast in traditionally female roles, like caretaker, nurse, TVsalesperson sidekick, housewife, mother, wife and lover. As such, the message the film conveys is that of the traditional fairy tales: that happiness for a woman may only be achieved if she conforms to the gender scripts of patriarchal society. According to the clichéd feminine quest pattern, Liza has to learn to navigate the feminine spaces of Csudapest, leaving her room of girlhood for the greater womanly spaces of the kitchen and the master bedroom. Thus Liza learns how to cook for, and how to live with a man, respecting the male spaces and activities - the necessary repairs around the house for example are left to Zoltán - and how to transform herself into a desirable sexual temptress instead of the nondescript girl she had been for most of her life. This metamorphosis requires her to sew her own dress, another female activity, and by donning the self-made white dress she becomes femme fatale and virgin bride in one. 
Benczik, Vera. “Gendered Quest in Recent Hungarian Fantasy Films.” Hungarian Cultural Studies. e-Journal of the American Hungarian Educators Association, Volume 12 (2019) DOI: 10.5195/ahea.2019.365

Liza communicates the need for the female protagonist to possess a sexualized female body in order to find a partner, as men are only attracted to her after she follows the fashion and make-up conventions of her age. Her being thirty years old at the outset of the story conveys the notion that her biological clock is ticking and that she has to hurry with her quest if she still wants to fulfill her female duty of bearing children. Similarly to non-conformist characters in the traditional cautionary tales, transgressive women in Liza are condemned to failure. For example, Aunt Márta, although she embodies the utmost passivity of the ideal woman by being confined to the bed, dies unhappy and alone, probably as punishment for her infertility, while Inge, Liza's sensual and sexually independent downstairs neighbor is also doomed to rejection, in her case, in contrast, for her sexually promiscuous life. Liza manages to overcome the obstacles she encounters on her quest, and successfully rejects agency by refusing to construct herself as the fox-fairy, the bringer of death to the men in Csudapest. Instead, she transforms into the figure of Snow White, re-enacting the fairy tale character's feminine passivity after she overdoses on sleeping pills - a modern-day version of the poison apple - and waits as a proper damsel in distress for her prince to rescue her from the dragon. The film ends after a time jump of several years with the now complete family - a daughter has joined Zoltán and Liza - travelling in Japan, listening to "Ievan Polka" ['Eve's polka'], a famous Finnish song about a girl growing up to be a woman, and leaving her mother for a man.

\section{Conclusion}

Despite the recent trends in international fantasy and science fiction films to produce what Cristian and Dragon call "negotiated cinema" (Cristian and Dragon 2008), feminist films building on traditional patriarchal templates, but disengaging gender representations from stereotypical depictions, Hungarian genre films still tend to rely on more traditional quest blueprints when addressing issues related to gender roles. Loop concentrates on the protagonist having to process the acceptance fatherhood, simultaneously re-enacting the Campbellian stages of the monomyth, but arguably also digressing from the traditionally hypermasculine male quest's topology by concentrating on parental responsibilities as the quest objective. In contrast, Liza, the Fox-Fairy remains within the boundaries marked out by the patriarchal system for the questing heroine. Invoking the techniques of the cautionary fairy tale, conservative Japanese cultural practices, and a nostalgia-infused displacement of Budapest, the narrative communicates the need for females/women to conform to patriarchal gender scripts as the only way to complete the female quest successfully. Thus it seems to send a message that discourages independence and agency, and embraces the cult of domesticity as the blueprint for a proper transition from girlhood into womanhood. Although the two films do not reflect on Hungarian cinema as a whole, they are representative for the prevalence of conservative gender representations within modes of the fantastic in contemporary Hungarian film.

\section{Works Cited}

“2018 Domestic Grosses: Total Grosses of all Movies Released in 2018.” Box Office Mojo. Web. https://www.boxofficemojo.com/yearly/chart/?yr=2018\&p=.htm

Alien. 1979. Dir. Ridley Scott. Twentieth Century-Fox Productions. Aura ['Aura']. 2014. Dir. Zsolt Bernáth. Sherlockfilm.

Bathgate, Michael. 2004. The Fox's Craft in Japanese Religion and Culture: Shapeshifters, Transformations and Duplicities. New York: Routledge. 
Benczik, Vera. “Gendered Quest in Recent Hungarian Fantasy Films.” Hungarian Cultural Studies. e-Journal of the American Hungarian Educators Association, Volume 12 (2019) DOI: 10.5195/ahea.2019.365

Bollobás, Enikő. 2018. "The Fantastic as Performative. Mark Twain and Ambrose Bierce Performing the Unreal." Posthumanism in Fantastic Fiction. Ed. Anna Kérchy. Szeged: AMERICANA eBooks, 9-20.

Buffy the Vampire Slayer. 1996-2003. Dir. Joss Whedon. Twentieth Century-Fox Television.

Campbell, Joseph. 2004. The Hero with a Thousand Faces. Princeton, NJ: Princeton University Press.

Cristian, Réka M. and Zoltán Dragon. 2008. Encounters of the Filmic Kind: Guidebook to Film Theories. Szeged: JATEPress. Kindle file.

Eddison, Eric Rücker. 2014. The Worm Ouroboros. London: HarperCollins.

Edge of Tomorrow. 2014. Dir. Doug Liman. Warner Bros. Pictures.

Frye, Northrop. 1990. Anatomy of Criticism. Princeton: Princeton UP.

Gilbert, Sandra M. and Susan Gubar. 1987. “The Queen's Looking Glass.” Don't Bet on the Prince. Contemporary Feminist Fairy Tales in North America and England. Ed. Jack Zipes. London: Routledge, 201-208.

Gilbey, Ryan. 2013. "Same again, thanks." The Sydney Morning Herald 12 Feb. 2013. https://www.smh.com.au/entertainment/movies/same-again-thanks-20130212-2eayx.html

Groundhog Day. 1993. Dir. Harold Ramis. Columbia Pictures.

Hegyi, Pál. 2019. Lovecraft Laughing: Uncanny Memes in the Weird. Szeged: AMERICANA eBooks. Kindle file.

Hume, Kathryn. 1974. "Romance: A Perdurable Pattern.” College English 36.2: 129-146.

Hurok ['Loop']. 2016. Dir. Isti Madarász. Café Film.

Irvine, Alexander C. 2012. "Urban Fantasy." The Cambridge Companion to Fantasy Literature. Eds

Edward James and Farah Mendlesohn. Cambridge: Cambridge UP, 200-213.

Kontroll ['Control']. 2003. Dir. Nimród Antal. Café Film.

Liza, a rókatündér ['Liza, the Fox-Fairy']. Dir. Károly Ujj Mészáros. FilmTeam, 2015.

MacDowell, James. 2012. "Wes Anderson, Tone and the Quirky Sensibility." New Review of Film and Television Studies 10.1: 6-27.

Mendlesohn, Farah. 2008. Rhetorics of Fantasy. Middletown, CT: Wesleyan UP.

Red Sonja. 1985. Dir. Richard Fleischer. Dino De Laurentiis Company.

Rowling, J. K. 1999. Harry Potter and the Prisoner of Azkaban. London: Bloomsbury.

Sherman, Fraser A. 2016. Now and Then We Time Travel: Visiting Pasts and Futures in Film and Television. Jefferson, NC: McFarland.

Suvin, Darko. 1979. Metamorphoses of Science Fiction. Cambridge, MA: Yale UP.

Varga, Ákos. 2016. “Zsánerek útvesztőjében. Müfajok és müfaji elemek a kortárs magyar filmben.” [In the Genre Labyrinth: Genres and Genre Elements in Contemporary Hungarian Cinema]. Apertúra 11.4. Web. http://uj.apertura.hu/2016/nyar/varga-zsanerekutvesztojebenmufajok-es-mufaji-elemek-a-kortars-magyar-filmben/

Vonnegut, Kurt. 1998. Timequake. New York: Berkley.

Xena: Warrior Princess. 1995-2001. Prod. Sami Raimi, John Schulian, R. J. Stewart. MCA Television. 